\title{
Of Tales and Tellers: Trust-but Verify
}

\author{
John Rodden ${ }^{1}$
}

Published online: 3 November 2017

(C) Springer Science+Business Media, LLC 2017

\section{"Between" Self and Society}

"Psychological novel" is a loose term, frequently applied to those first-person novels that reflect narrative techniques such as "stream of consciousness" or explore the individual psychologies and interior conflicts of fictional characters in detail and depth. I find that interpretation far too restrictive. Prose classics such as William Godwin's Caleb Williams, Thomas Hardy's The Mayor of Casterbridge, and D. H. Lawrence's Women in Love are seldom classified as "psychological novels," yet their accent on larger public issues rather than intimate personal matters-Gemeinschaft and Gesellschaft rather than consciousness and mentalité, exterior rather than interior conflicts - reflects a need to expand our traditional conception of the psychological to include the societal, cultural, intellectual, and even spiritual if we want to embrace the full scope and dynamics of personality. It is important to resist reducing the terms "psychology" and "novel" to the exclusively mental or narrowly aesthetic, letting them instead retain all their suggestiveness and acculturated history of meanings.

I recently completed a study that pursues this effort to broaden the scope of the psychological in the course of reinterpreting several modern British novels, some of them unjustly neglected and even denigrated as ambitious stillbirths. Titled Between Self and Society: Modes of Narration in the British Psychological Novel, my book scrutinizes the rhythms of psyche and demos in the history of British fiction since the mid-eighteenth century. As the main title suggests, these rhythms are complex, ramified, and multifaceted: the

John Rodden

jgrodden1@gmail.com

118 Beautybush Trail, Georgetown, TX 78628, USA interrelations between "self" and "society" are not either/or, but rather both/and - in fact, almost always "in between." Indeed the emphasis alternates between the individual and the community, the particular and the universal—self and society - namely, the polarities of conflict that in turn motivate and shape character in these diverse worlds of prose fiction. A psychological "case history" of the British novel thus serves as an index of the affective range of the genre, variously illuminating its representation of personality and mental life, the textual features of emotional expression, and the reading experience to which real readers have testified. This essay serves as a condensed report of the conceptual issues involved in this case history.

\section{Putting the Novel "On the Couch"}

By widening our angle of hermeneutic vision to accommodate the vista across which character and personality unfolds, we appreciate more fully their variety and amplitude - and are inevitably led to revise our constricting critical shibboleths about the "psychological novel."

Consider, for instance, the familiar quandary of the "untrustworthy" narrator in a trio of novels all-too-readily dismissed as romans manqués: Tobias Smollett's Roderick Random, Godwin's Caleb Williams, and Ford Madox Ford's The Good Soldier. All three address narratological questions, especially controversial issues connected with "untrustworthy" narrators, their modes of storytelling, and their dubious claims to truth. One could well gloss them "Untrustworthy Tellers, Unverifiable Tales," with a nod to Lawrence's famous remark in Studies in Classic American Literature: "Trust the tale, not the teller." But my proviso and critical maxim would echo, as the subtitle of this essay reflects, the Russian proverb much quoted during the Cold 
War by wary American leaders negotiating nuclear disarmament with the Soviets: doverey no proverey, "trust but verify."

Honoring this maxim - and resisting the lures of reductionism that bestow conceptual tidiness and analytical rigor at the expense of widened apprehension, nuanced understanding, and even occasionally revelatory surprise - is crucial to a judicious assessment of the value and vicissitudes of the psychological novel. As I have suggested, too often the prevailing verdict about some or all such prose fictions, whether pronounced by formalist or social critics, is that novels such as Caleb Williams, The Good Soldier, and Wyndham Lewis's Tarr represent admirable and valuable, indeed even fascinating or pioneering literary experiments - yet ultimately prove artistic failures. Such novels are often considered crude, schematic, loaded with structural improbabilities (such as clumsily handled coincidences or ungrounded motivations or fuzzy treatments of time). When looked at either from an aesthetic/ formal viewpoint that would illuminate a Henry James novel, or from a social/political stance pertinent to the work of George Eliot, they are typically judged inferior fictions. But if we look at these novels from the standpoint of depth psychology — which attends variously to eros, inner identity, and concealed conflicts in the protagonist and other characterswe can perceive an artistic unity and stylistic consistency often missed by surface readings.

On this view, close readings of these novels represent a critical study in the psychology of character. Or, to phrase it more precisely, a study in character analysis through psychology, especially as it is revealed by a character's unconscious drives or by a narrator's distorted memory and consequently problematic mode of narration. While much of the extant scholarship is cogent and insightful, I would argue that it must be extended in directions that can offer new readings of novels that have been misunderstood, read too restrictively, and therefore devalued. My readings of the aforementioned novels, for example, draw on psychological approaches and psychoanalytic concepts, which - perhaps surprisingly-constitute resources seldom exploited to understand these fictions.

What is the advantage of such an approach? Traditionally, some of these novels (e.g., Caleb Williams, The Good Soldier, Tarr) are castigated as political treatises, as almost tract-like analyses of social and economic forces. Supposedly heedless of aesthetic form, they suffer from awkward plot development and flat characterization, rendering them little more than sketchbooks illustrating this or that social evil. By contrast, my own critical premise is that these ambitious, frequently trailblazing novels are, however flawed, fictional masterpieces which have been unjustly neglected or undervalued, largely because they have violated or defied reigning fictional norms and conventions. I contend that they repay fresh critical reappraisal from sympathetic readers. For instance, if we approach these fictions via depth psychology, we can see how a plot that looks random or forced is actually a projection of the narrator's anxieties. Given that approach, the four novels already mentioned - by Smollett, Godwin, Ford, and Lewisemerge as complex, challenging works of art, because we better comprehend how form and structure model or correlate with the inner life of the characters. This way of reading opens up the novels to possibilities not addressed in the secondary literature so far.

By no means would I restrict the term "psychology" to Freudianism or depth psychology. For instance, I have found it enormously fruitful to depart from a psychoanalytic interpretation when another mode or conception of "psyche" and "eros" has proven more pertinent and promising, as, for instance, when I propose a Lawrentian reading of Lawrence's Women in Love. Lawrence's famous hostility to Freudianism is well known, manifested in much of his fiction and made explicit in his antiFreudian polemics, Psychoanalysis and the Unconscious (1921) and Fantasia of the Unconscious (1922). From this angle, Women in Love presents its London Bohemiansespecially Loerke and Minette Darrington-as exemplars of "mental consciousness," a pathology indicted by Lawrence as the disease of the Northern European mind, allegedly epitomized by Freud, Jung, and their followers. Such Nordic intellectualism, claims Lawrence, heightens and intensifies mental consciousness and thus contributes to neurosis. It reflects an antipathy toward the body and spiritual health that stand opposed to his vitalistic philosophy of "blood consciousness," the cornerstone of Lawrence's racial theory that critics have derided as both misogynistic and anti-Semitic.

Regardless of our judgment of Lawrence's philosophy, however, it undeniably undergirds the Weltanshauung of much of his fiction, especially Women in Love. It is not just a philosophical viewpoint, but rather represents his own serious, passionately argued attempt to plumb the dynamics of eros and psyche. As such, "Lawrentian psychology" functions as an experience-based metaphysics of the psyche, formulated by a literary artist resolutely antagonistic to Freudian social science and "depth" psychology, indeed to the purportedly "Jewish" psychoanalysis of Freud and his immediate circle.

I draw here on the example of Lawrence to stress that I advocate a nondoctrinaire, inclusive approach to the psycholiterary analyses of this labile genre, the "psychological novel." All such novels should be addressed not only from the vantage point of the institutional, "outer" conflicts (family, class, society, status) that they overtly treat, but also from the perspective of the often overlooked psychological, "inner" conflicts that sometimes elevate these works to tragic stature. This dual emphasis is indispensable to a full appreciation of these complex fictions because their psychological aspects are more crucial than the social analyses to the novels' latent meanings and submerged structures. 
Toward a Psychological "Case History" of the British Novel

Which "psychologists" do I suggest as most suitable for revaluing possibly "misunderstood" masterpieces? I have no list, but rather simply my own discoveries as to which hermeneutic tools in the psycho-toolbox have assisted my own "psychological investigations." In my explorations of the fictive representations of personality in the British novel, I have made much use of psychological theory in the work of thinkers such as Sigmund Freud, Melanie Klein, Otto Rank, Ernest Becker, and René Girard, among others. The psychological novel often seems not just to invite attention to the kinetics of psyche, eros, and demos, but to organize affect into a linguistic construct that stages dramas of the passions. In this regard, theorists of personality development and character structure from Freud through Girard offer valuable insight into the texture of experience prevailing within narrative designs.

Freud and his successors concurred that a basic characteristic of human experience is the limited nature of our freedom. They all agreed that the realm of conscious choice is confined within severe limits. Novelists from Smollett to Lawrence and beyond have voiced greater skepticism about these matters, refusing to portray the deeds of human beings as largely the product of material or psychological conditioning - which is to say that literary artists have adamantly resisted becoming social scientists. They have acknowledged with Freud that the presumably conscious aspects of human experience might be mere "rationalization" or "repressed desire" or puzzling instances of displacement, projection, and introjection. And yet, in their conception of the inevitable role of "vast impersonal forces" in the conduct of human affairs, novelists have also always insisted on depicting individual choice and conscious mental activity. In a metaphysical and ethical sense, that is, if not in a collective or statistical sense, they have believed that choice-making is personal and that individual choice is free. This is not to say that they deny the significance of the repetitive, irrational, and instinctual in human life, only that they hold that such subterranean drives have their limits - and that the art of the novel consists in exploring the interacting and overlapping relationship between self-determined acts and conditioning forces.

The modern Western novel both reflects and has shaped the modern mind. In addition to the thematics of choice-making and psychic freedom, a leitmotif of literary history is the unfolding, intensifying perception of psychological malaise as the modern novel evolves: a sense of an impending doom, whereby old practices and institutions no longer undergird social reality, a climate of radical uncertainty that pervades novels ranging from Hardy's The Mayor of Casterbridge through the modernist fictions of Ford, Lewis, and Lawrence. This sense of the demise of the ancien régime, coupled with agonizing doubt as to what brave new worlds might follow, represents a thematic undercurrent of my book. The emphasis in my studies of these authors' works is not only on modes of consciousness, but also on the increasing prevalence in modern society of "divided" consciousness.

As such, a psychological "case history" of the novel may also be seen as a counterpart to, or even extension of Ian Watt's The Rise of the Novel: Studies in Defoe, Richardson and Fielding (1957). Whereas Watt's book addressed the origins of the novel in historical and formalist terms, a "psychohistory" traces the rise of the novel chiefly in psychological terms, showing how a movement exists from the "narcissistic" fictions of the eighteenth century, exemplified by Smollett's Roderick Random and Godwin's Caleb Williams, to the psychodynamics of character in the novels of the late nineteenth and twentieth centuries, ranging from Hardy to Lawrence and beyond. Watt's thesis in The Rise of the Novel was that "the whole question of the historical, institutional, and social context of literature is very widely ignored, to the great detriment not only of much scholarly and critical writing, but of the general understanding of literature at every educational level." That was certainly true in the 1950s, given the ascendency of New Criticism and its insistence that texts exist "independently of each other," in Watt's phrase. But one can also say today that the psychological aspect of the British novel is too widely ignored, to the detriment of scholarship, criticism, and education. This deficiency reflects a deepseated, long-standing bias in British studies to prefer the empirical, including an almost reflexive antipathy toward psychological inquiry. (Or as the Irish novelist John Banville, who shares the familiar contempt of the empirical Brits for "head shrinking," likes to joke upon hearing critics mention the word "psychology" in relation to the novel: "I reach for my revolver.")

British skepticism toward psychological approaches to literature has heightened since the 1920s and 1930s, partly in reaction to what was often referred to as the "psychoautopsies" of sensationalist British biographers and literary critics in the wake of the success of Lytton Strachey's Eminent Victorians (1918). Like Watt, who maintains that selective use of biographical, historical, and formalist criticism is indispensable for understanding the rise of the novel, I believe that psychological interpretation is also invaluable, especially for novels that deal in complex ways with narratology and the psychology of character. My own view about the value of psychology for illuminating art and literature mirrors the stance of Robert Penn Warren: "There is no one, single, correct kind of criticism, no complete criticism. You only have different kinds of perspectives, giving, when successful, different kinds of insights." 
Speaking to his community of fellow literary critics in the mid-1950s, Louis Fraiberg voiced a concern that is a locus classicus for me when I reflect on my own work:

If we are to derive the greatest benefit from psychoanalysis in our study of the creative process - or any other literary problem for which it has relevance - we must always keep before us the difference between our way of looking at literature and the psychoanalyst's. Since they are not the same, this means that in order to make intelligent use of psychoanalytic findings and theories, we need to understand where they came from and how they were arrived at. To put it bluntly, we must know psychoanalysis as well as we know literature and criticism.

\section{Re-imagining Inner Life through Imaginative Literature}

Finally, let me add a word here about "grand theory" that may run counter to the postmodern Zeitgeist. The theorists whom I have cited-Freud, Klein, Rank, Becker, and Girard-were builders of ambitious interdisciplinary systems. We of the postmodernist age have learned to cast a skeptical eye on such monumental system-building. Yet however schematic the patterns and procedures it imposes, such system-building contrasts fruitfully with the fictional texts on which such theories are often tested or applied. The novel consists of loamy, organic particulars that generate fertile insight as they complicate the generalizations and universals of social science. Our primary critical concern should be with the fictions themselves, for these novels represent something far more valuable than opportunities for literary exegesis: they suggest - indeed they imagine - the possibility of new perceptions of character structure and personality development.

Freud and later psychologists came to see the study of society as an immensely more complicated matter than merely fitting observed data into presumably universal constructs of human thought. This growing methodological awareness reflected a heightening of intellectual self-consciousness among social scientists that is a characteristic of twentiethcentury psychology. They could begin to glimpse how the narrative issues in the modern novel — of "trustworthiness," dream logic, and so on - portray this new awareness of the problematic character of social observation. But this new selfconsciousness among intellectuals frequently slipped into a radical skepticism: It was a short step from the awareness of the subjective nature of social thought to a denial of the validity of all such thought - into a form of Lawrentian "think with the blood" or other species of anti-intellectualism.

Imaginative literature - most particularly the novel-has played a serious role in the expression of social values. A major novel manifests and concretizes the often abstract insights of social scientists. It depicts society with a richness and depth that eludes social science categorizations. So my own critical goal is not simply to see how prose fiction has borrowed from social science, but also to see how it has contributed to social theory: that is, my dual aim is to appreciate the dense interplay of mutual influence between these genres. For the student of human society has much to learn from the literary craftsman, and vice versa: the sensibilities and subject matters of both domains illuminate the art of living.

\section{Further Reading}

Frailberg, L. 1955. "Literature and Psychology: A Question of Significant Form," Literature and Psychology Vol. 5.

Lawrence, D. H. 1923. Studies in Classic American Literature. New York:Thomas Seltzer.

Rodden, J. 2016. Between Self and Society: Modes of Narration in the British Psychological Novel. Austin: University of Texas Press.

Warren, Robert Penn. 1958. Writers at Work: The Paris Review Interviews, ed. Malcom Cowley. New York: Viking Press

Watt, I. 1957. The Rise of the Novel: Studies in Defoe, Richardson and Fielding. Berkeley: University of California Press.

John Rodden Senior Editor of Society, has written several books on British, American, and German literary history. 